\title{
Tubuh Tari Indonesia Sasikirana Dance Camp 2015-2016
}

\author{
Eko Supriyanto \\ Institut Seni Indonesia Surakarta, \\ Jalan Ki Hajar Dewantara no. 19, Jebres Surakarta, 57126 \\ Email: ekosdance@yahoo.com
}

\begin{abstract}
Sardono W. Kusumo, an Indonesian dance master and choreographer, once stated that the way to understand dance should start with the study of embodiment before moving to the study of dance in its performative art form. A dancer should be able to process his/her dance by recognizing the complexity of the body and the nerves system and muscles through a creative process, resulting a confident work of performing arts. Through a historical perspective and based on the theory of embodiment, this article tries to convince that dance needs to stand as a repository of cultural memories and therefore is able to represent the habitus of Indonesian dancers. A comprehensive evaluation of the development of Indonesian Dance Festival (IDF) and Sasikirana Dance Camp (SDC) is used as real evidences of how this form of the arts must put forward physical approaches first before creating a reasonable discourse to the acts.
\end{abstract}

Keywords: dance camp, choreography lab, embodiment

\begin{abstract}
ABSTRAK
Sardono W. Kusumo, maestro dan penata tari Indonesia, mengungkapkan bahwa untuk memahami tari harus dimulai dengan mempelajari ketubuhannya sebelum bergerak pada studi tentang tari dalam aspek performatif pertunjukannya. Seorang penari harus mampu memahami dan mendalami kompleksitas tubuh bersamaan dengan system syaraf dan otot tubuhnya sebagai proses kreatif untuk kepercayaan tubuhnya dalam pertunjukan. Melalui perspektif sejarah dan bersumber pada teori ketubuhan, tulisan ini bertujuan memberikan perspektif, bahwa tubuh tidak hanya sebagai tempat agensi kultur masa lalu, sehingga lebih meyakinkan bahwa tubuh tari Indonesia berakar dari habitatnya. Evaluasi komprehensif atas kegiatan Indonesian Dance Festival (IDF) berserta Sasi Kirana Dance Camp $(S D C)$, dijadikan sebagai pembuktian tentang pentingnya pendekatan fisikal untuk ketubuhan penari sebelum merujuk pada pendekatan bidang seni lainnya.
\end{abstract}

Kata kunci: dance camp, lab koreografi, tubuh tari 


\section{PENDAHULUAN \\ Studi Tubuh Tari}

Sebelum memulai dengan penjabaran tentang kondisi tari di Indonesia, berikut kutipan yang diambil dari wawancara penulis dengan Sardono W. Kusumo, tokoh tari Indonesia, penari dan koreografer serta guru besar bidang penciptaan tari di Institut Seni Indonesia Surakarta dan Institut Kesenian Jakarta, mengenai tari dalam ruang lingkup studi tubuh sebagai akarnya, dan tari dalam ranah studi pertunjukan dengan segala aspek performatifnya.

"Tari merupakan hasil dari penjelajahan tubuh dalam mengenali kompleksitas otot melalui seni, dan kolaborasi dari kedua unsur ini menghasilkan keyakinan untuk mengekspresikan gerak tari dari masingmasing individu. Jika misalnya, Martha Graham banyak mengeksplorasi ceritacerita tragedi Yunani, Chandraleka dari India mengolah dasar pertunjukannya dari konsep-konsep Yoga, Hindu, dasa rupa, nawa rasa serta gerak-gerak mudra dari tari India, maka konsep Budhism Jawa justru sebaliknya, tidak menunjukkan pola-pola ekspresi yang vulgar, terbukti dengan puncaknya di tarian-tarian Bedhaya atau Alusan; ekspresi gerak tanpa emosi dan datar ini bersumber dari konsep Vipasana, yaitu mengalir pelan, mencapai puncaknya dengan rasa yang terkendali." (Wawancara Sardono W. Kusumo, 2014).

Berdasarkan pengalaman seniman yang biasa dipanggil 'Mas Don' ini, misalnya, tari Dayak memberikan keleluasaan untuk menjadi netral (neutral), tanpa pretensi dan tidak merujuk pada karakter lain selain ekspresi tubuhnya. Hal ini berbeda gerak tari Jawa memiliki yang studi ketubuhan yang paling miskin. Pertunjukan tari Jawa mengedepankan unsur tontonan, bersama pemain gamelan yang berjumlah puluhan termasuk racikan instrumen gamelannya, kerangka cerita yang besar dari kesusasteraan Mahabarata atau cerita Panji, arsitektur Pendopo yang besar dan mewah, serta atribut kostum yang kompleks. Seluruh unsur ini menjadikan pertunjukan tari Jawa menonjol secara performatif, dengan dikedepankannya unsur pertunjukan yang kaya dan besar.

Mas Don merasakan terjadi perbedaan yang signifikan pada gerak tubuhnya ketika ia berada di tengah hutan di pedalaman Dayak dibandingkan dengan saat ia menarikan tari Jawa Alusan di pementasan Ramayana Balet di Candi Prambanan. Tarian tubuhnya di Dayak mengandung unsur ketubuhan yang sangat kaya karena tidak terbelenggu oleh karakter tertentu. Ia ha-nyalah seorang Sardono yang mengespresikan gerak tubuhnya, menjerit dalam ruang "hutan" yang tanpa batas. Dilihat dari perspektif ini, mas Don beranggapan bahwa Joged Jawa yang telah terpolakan menjadi aspek tontontan sulit untuk menjadi kasus studi tubuh karena mengandung unsur yang terlalu banyak.

Tari Jawa bukan merupakan studi dasar pemahaman ketubuhan karena tidak bisa dilihat dari sudut pandang yang tunggal. Misalnya, kajian ketubuhan tari bedaya harus melibatkan kajian terhadap sembilan orang penari dengan sembilan karakter, dengan dasar meditasi individual yang tidak ditafsirkan secara tunggal, apalagi menyangkut gerak tarinya. Semua tercermin pada ekspresi masing-masing gandar atau bentuk tubuh penari bedayanya. Tari bedaya adalah sebuah contoh konkrit (jika tidak merujuk pada aspek tontonannya) sebagai puncak ekspresi kesenian yang terwakilkan dari ekspresi ruang tubuh pribadi, dengan masing-masing penari yang memberikan santunan ekspresifitas tubuh, yang sinerji solo/tunggal dalam sebuah susunan tari.

\section{Tubuh, Gerak, Tari dan Proses Penciptaannya}

Merujuk pada pernyataan Sardono, tubuh tari Indonesia adalah tubuh yang multikultural, tubuh yang tidak hanya berkutat pada pola spektakularitasnya sebagai pertunjukan. Tari di Indonesia merupakan tarian yang mengarah pada kompleksitas ketubuhan berbasis budaya, adalah tarian yang semestinya merayakan kebebasan pribadi, 
dan membuka kebebasan pascakultural. Sehingga tari dalam konteks studi ketubuhan seharusnya dapat menyediakan ruang berekspresi secara individual, membukakan ruang eksplorasi, dalam menemukan gerak pribadi dengan segala efektivitas dan kompleksitas ketubuhan masing-masing pelakunya (Supriyanto, 2014: 337). Di sisi lain, hal yang perlu disadari, adalah bahwa saat ini masyarakat kita semakin mengedepankan unsur fisikal. Tubuh menjadi komoditi bisnis, gincu, lipstik, rambut palsu, pembesar payudara, pewangi ketiak, dan lain-lain. Tubuh didudukkan pada posisi untuk menopang jiwa zaman (zeitgeist) karena terkait dengan benda-benda seperti mal, mobil, pakaian, tempat-tempat pelancongan, restoran mewah, dan sebagainya. Tubuh manusia sekarang dideterminasi oleh keadaan yang menentukan kuasa, sistem kapitalis, franchise, dan lain-lain. Bisnis semakin merebak, untuk memiliki motor atau mobil pun semakin mudah; museum-museum digusur untuk mal, anak-anak tidak mempunyai taman untuk bermain (Supartono, 2016). Tidak dapat dipungkiri, kecenderungan terhadap komodifikasi tubuh dan jiwa materialisme mempengaruhi pola pikir masyarakat dalam memaknai dan bereaksi terhadap lingkungan serta persoalan yang berkutat di sekelilingnya.

Selanjutnya, perjalanan tari di Indonesia harus dilihat dari praktikal tekniknya baik tari tradisional, tari kontemporer maupun tari-tarian lain yang berasal dari kultur dan budaya yang lain, seperti modern American, Ballet, Jazz, Hip-hop, dan masih banyak pengkotak-kotakan definisi tari lainnya. Tulisan ini lebih memfokuskan pada bagaimana tubuh penari atau media tari yang paling utama adalah gerak, menjadikannya orientasi fokus serta penjabaran utama. Tulisan ini mengkaji studi tubuh sehubungan dengan langkah konkrit penciptaan tari yang bersumber dari gagasan proses kreatif masing-masing seniman tari.
Tari kontemporer dapat dilihat dari banyak perspektif, namun dalam hal ini, dapat diartikan sebagai tari yang secara kreatif membawa pesan kekinian atau modernisasi yang berkolaborasi dengan tari tradisi. Kolaborasi yang dimaksud adalah padupadan, keterkaitan, dan keterjalinan dari baru dan lama. Kolaborasi ini menciptakan sebuah gagasan idea dan bentuk yang berbeda dari yang sudah ada, walaupun masing-masing masih dapat merujuk pada akar yang lalu dan yang kini. Selebihnya, tradisi atau yang lama, adalah gugusan nilai-nilai budaya yang mapan dalam kurun waktu yang cukup panjang, sedangkan yang baru adalah yang bersifat sementara (kontemporer) yang gagasan serta bentuknya adalah nilai-nilai budaya baru yang sedang mencari sosok kemapanan (Murgiyanto, 1998: 256). Berbeda dengan pembentukan tari kontemporer di Barat, tari kontemporer di Indonesia menjadikan tradisi sebagai akar dari karyanya dengan cara mengunjungi, mempertanyakan dan menginterpretasikan kembali tradisi serta mengimplementasikannya pada gagasan karya cipta baru. Hal ini menandakan bahwa inovasi adalah bagian dari tradisi yang tidak bisa dikhianati keberadaannya (wawancara Raditya, 2016). Bentuk tari kontemporer pun diartikan sebagai ungkapan dalam bentuk kreativitas yang sarat akan pertanyaan dan kritik terhadap keadaan yang lama 'tradisi'.

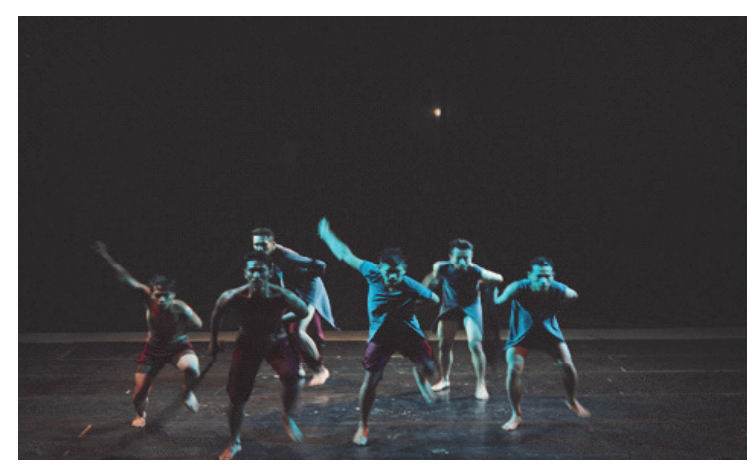

Gambar 1. Tari Kontemporer berjudul “Tra.jec. to.ry" karya Eko Supriyanto, 2016. Dokumentasi NuArt Sculpture Park (Fotografer: Yulli Adam Pandji) 
Studi Tubuh dan Sasikirana Dance Camp

Di sinilah letak pentingnya studi tubuh yang tidak hanya berorientasi pada aspek tontonan atau performatif dalam sebuah garapan tari kontemporer. Jika para penari dan koreografer telah menyadari dan menyepakati bahwa tubuh dan kompleksitasnya dapat menjadi ekspresi pribadi maka seniman dapat membuktikan bahwa tubuh dalam tari adalah hal yang paling utama (Supriyanto, 2014: 341). Tulisan ini berlanjut dengan menjabarkan program studi ketubuhan yang dilakukan oleh Sasikirana Dance Camp tahun 2015 dan 2016 di NuArt Scupture Park, Bandung, Jawa Barat. Program ini muncul sebagai salah satu contoh laboraturium untuk penari dan koreografer dengan kembali menyepakati pendekatan fisikal dalam tari sebagai landasan utama dalam studi tubuh dan capaian kreativitas tari kontemporer Indonesia.

Gerak dan tari adalah satu aktivitas yang merujuk tubuh sebagai pendekatan nyata untuk menjadikannya sebagai langkah kreatif dengan trajektori yang jelas dalam proses penciptaan tari kontemporer di Indonesia. Tulisan ini tidak hanya akan berkutat pada permasalahan metode pelaksanaan teknik acara Dance Camp dan KoreoLab, tetapi akan lebih dalam lagi menelaah praktik yang berupa mentoring, menganalisa dan mendiskusikan proses kepenarian dan koreografinya, dan bagaimana studi tubuh untuk tari pada saat ini menjadi sangat mendesak agar penari dan koreografer di Indonesia agar tidak kehilangan subtansi pendekatan awal tubuh dan pendekatan fisikalnya.

Sebagai ilustrasi, penulis mengawali isi tulisan ini dengan penelusuran historis perkembangan program Indonesian Dance Festival yang kemudian menjadi titik tolak pemikiran kritis terhadap kondisi ketubuhan penari Indonesia saat ini, dan mengapa pemahaman akan ketubuhan menjadi krusial untuk disoroti. Kerangka yang digu- nakan dalam tulisan ini menggunakan pendekatan teori ketubuhan dengan mengaitkannya dengan paradigma strukturalis yang mencermati adanya peranan agen dalam pengembangan tari kontemporer di Indonesia. Melalui perspektif ini, diharapkan muncul kesepakatan bahwa bagaimana pun perkembangan tari kontemporer Indonesia perlu berjalan dalam sebuah sistem infrastruktur yang kokoh agar mampu mencapai pemahaman mengenai identitas ketubuhannya.

\section{METODE}

Kajian tentang identitas ketubuhan ini menggunakan metode penelitian kualitatif yang melibatkan pendekatan participation action research dalam kerangka multidisiplin. Jenis pendekatan yang dielaborasikan secara deskriptif analitis ini dianggap tepat karena mampu menuturkan, menggambarkan, dan mengkonstruksi pemahaman mengenai teori ketubuhan dengan data yang didapati di lapangan mengenai subjek kajian dalam tulisan ini. Pendekatan ini diharapkan mampu menunjukkan kompleksitas ketubuhan tari di Indonesia dalam kerangka yang holistik.

Untuk kajian, penulis melakukan pengumpulan data berupa observasi, wawancara, studi pustaka, dan studi dokumentasi. Hal ini dilakukan karena analisa terhadap kajian ini melibatkan rentang waktu yang cukup lama dan melibatkan partisipasi langsung dalam subjek dan objek kajian yang dituliskan. Dalam hal ini, partisipasi langsung dijalani oleh penulis dalam kedua studi kasus yang digunakan dalam tulisan ini, yaitu Sasikirana Dance Camp sambil mengikuti dan terlibat dalam perkembangan Indonesia Dance Festival selama beberapa belas tahun terakhir. Melalui metode pengumpulan data, penulis mampu mengolah gagasan, ide dan praktik di dunia tari dihubungkan dengan berbagai teori yang digunakan untuk mengkaji studi 
ketubuhan di Indonesia yang menjadi subjek penelitian ini.

Dua contoh kegiatan seni tari yang dibahas dalam kajian ini menjadi konteks utama untuk menjelaskan teori ketubuhan dihubungkan dengan perspektif strukturalis dalam pembentukan konstruksi tubuh tari di Indonesia. Tulisan ini berusaha untuk memetakan beberapa agen yang terlibat di dalam kedua studi kasus dan bagaimana para agen tersebut bergerak dalam lingkup habitusnya untuk berkontribusi dalam perkembangan infrastruktur seni tari di Indonesia. Diharapkan, penelusuran historis dari contoh konkrit mampu memberikan pemahaman yang lebih baik mengenai subjek kajian ini.

\section{HASIL DAN PEMBAHASAN}

\section{Indonesian Dance Festival dan (bukan lagi) Perayaan Tubuh Tari Indonesia}

Indonesian Dance Festival (IDF), seperti yang dikukuhkan oleh pencetusnya, Sal Murgiyanto, merupakan ajang untuk mendampingkan karya-karya baru kreatif anak bangsa dengan menunjukkan kompleksitas ketubuhan kepenarian, intelegensi ke-Indonesia-annya dan merayakannya tubuh-tubuh dengan multikultur. Hal inilah yang menjadi landasan utama yang membingkai perbedaan IDF dengan festival tari di negara-negara lain. Kompleksitas training ketubuhan seniman tari Indonesia bersumber pada tradisi dan ragam kultur Indonesia yang majemuk yang mengungkapkan perbedaan identitas kultural yang beragam. IDF merupakan sebuah festival tari bertaraf internasional, yang bisa terwujud karena perasaan kehilangan atas Pekan Penata Tari Muda pada tahun 1990-an.

Pasca mundurnya Sal Murgiyanto sebagai pimpinan IDF, selanjutnya penyelenggaraan kegiatan ini dilaksanakan oleh direktur dan pengelola yang baru, yaitu antara lain Maria Darmaningsih dan Nungki Kusumastuti. Pada masa inilah kemudian banyak terjadi pergeseran pada substansi penyelenggaraannya, terlebih ketika festival ini menghadirkan para kurator dari luar negeri, seperti misalnya Tang Fu Kuen (Singapura) dan Daisuke Muto (Jepang) yang sedianya memberikan banyak kontribusi untuk memajukan IDF melalui wawasan dan keterlibatan para kurator internasional ini dalam kancah festival tari di Eropa dan Asia. Pergeseran yang terjadi terutama terlihat dari proporsi peserta IDF, yang sebelumnya didesain oleh Sal Murgiyanto untuk mempromosikan karya-karya penata tari muda Indonesia, namun kini berubah dengan semakin banyak ditampilkannya peserta mancanegara. Tidak hanya dalam nilai kuantitasnya, tetapi juga dalam pelaksanaan dan pemaknaan kebutuhan "internasional" yang mengharuskan panitia menerima sumbangsih seniman dan karya dari para donator wakil kultural negara Eropa maupun Asia. IDF akhirnya banyak juga mendaulat seniman atau intelektual di luar bidang tari untuk memperkokoh keleluasaan penyelenggaraan festival tari ini ke dalam wacana yang lebih lintas disiplin dan lintas bidang kesenian. Sebut saja kehadiran Helly Minarti (peneliti) atau Adi Wicaksono (sastrawan/perupa) dalam jaringan serta networker kesenian di Indonesia dan festival seni lain dari luar Indonesia.

Keterlibatan Minarti ataupun Wicaksono, memberikan secercah harapan bagi karya cipta koreografer muda Indonesia untuk dikelola lebih tertata dan terukur sehingga bisa disandingkan untuk produk karya tari anak bangsa di luar IDF (walau penulis tidak jelas melihat bagaimana proporsi keduanya akan pemahaman studi tubuh tari Indonesia). Mereka tidak hanya didaulat menjadi kurator seni pertunjukan Indonesia (khususnya tari), tetapi juga menjadi menjalani tugas-tugas yang sedianya dilakukan oleh dramaturg, produser, mentor dan pendamping seniman-seniman tari seperti Eno Sulistyani, Fitri Setyaning- 
sih, Ery Mefri berkolabarasi bersama Chintia Lee (USA) di IDF 2009, atau Ali Sukri bersama Arco Renz (Belgia) di IDF 2014.

Melihat perkembangan yang terjadi di lapangan, penulis berkeyakinan bahwa lebih tepat jika mereka disebut sebagai "makelar" tari kontemporer Indonesia yang dapat melihat gejala positif untuk menghantarkan karya-karya produktif dari generasi muda koreografer Indonesia ini ke dalam lingkup yang lebih luas. Keduanya menjadi pemantau dan tolak ukur beberapa progammer festival tari di Eropa dan Asia (terlebih Helly Minarti), dan keduanya pula menjadi penentu untuk mempromosikan karya tari kontemporer untuk generasi setelah Miroto atau Mugiyono. Posisi ini dapat bertugas sebagai penyambung antara para programer dan produser dari festival lain di Asia dan Eropa, yang sepertinya penting dilakukan untuk kelangsungan hidup dan masa depan tari kontemporer Indonesia. Dengan kemampuan argumentatif mereka untuk meningkatkan pemahaman para penari dan koreografer muda Indonesia, dapat mendampinginya agar karya tarinya lebih bisa 'terjual' di kancah dunia tari dan festival Internasional. Namun, penulis beranggapan bahwa analisa dan pendampingan mereka banyak menggunakan teori dan analisa studi performative, karena keduanya tidak pernah mengalami dan sangat tidak memahami kompleksitas ketubuhan yang terjadi pada penari dan koreografer di Indonesia. Argumentasi penulis menekankan pada pandangan, bahwa meski keahlian keduanya sangat penting sebagai pemerhati ataupun sebagai pendamping, namun mereka tidak pernah mengalami dirinya sebagai pelaku, tidak menampakkan pembuktian karya. Selanjutnya tidak menampakkan pemahaman pada tubuh kultural dan pasca kultural penari dan koreogafer Indonesia, padahal hal inilah yang menjadi urgensi, dan hal ini juga yang menunjukkan satu pergeseran besar pada konten di
IDF dalam beberapa tahun terakhir hingga diselenggarakannya IDF 2016 lalu.

Sebagai koreografer, penari dan dosen tari di Institut Seni Indonesia Surakarta, penulis adalah generasi yang lahir dan dibesarkan oleh IDF pada masa kepemimpinan Sal Murgiyanto. Program yang tidak hanya merekomendasikan karya-karya penulis dan teman-teman koreografer seangkatan, tetapi juga memberi pendampingan dan ruang diskusi yang panjang untuk mengerti dan mengartikulasikan segala hal, dari mulai proses penciptaan hingga terpresentasikannya sebuah karya. IDF pada masa itu mendampingi para koreografer muda dengan pendekatan dan analisa sebagai pelaku, di mana para pendampingnya juga telah memiliki pengalaman dalam berbagai proses penciptaan yang kompleks. Pendampingan ini melahirkan pemahaman teknik tari dan gerak tubuh yang dalam sehingga berdampak pada ketubuhan yang cerdas dan peka terhadap gagasan kontemporer. Tidak hanya berhenti ketika produk karya tari berhasil dipresentasikan, tetapi pendampingan ini terus berlanjut dalam ranah pendidikan, akademis dan konstruksi pikir yang kritis mengenai masa depan tari kontemporer Indonesia.

Pemahaman yang ditumbuhkan dalam proses pembelajaran tersebut membawa pada kesadaran bahwa tari Indonesia yang bersumber dari kekayaan kultural, tradisi serta vokabuler geraknya, tidak mengandalkan 'produk' sebagai agensi utamanya. Sebuah produk karya tari kontemporer menjadi tidak penting jika tidak didasari dengan kesadaran tentang kompleksitas gerak, vokabuler, dan kulturnya. Dalam tari, agensi yang berperan utama adalah 'tubuh', yang diperkaya dengan ragam vokabuler gerak, memori kultural serta ragam gerak pribadi yang privat, seperti yang sebelumnya disebutkan di merupakan argumen dari Sardono di awal tulisan ini.

Argumentasi penulis tentang perge- 
seran subtasi dan nilai yang terkandung dalam IDF, menjadi catatan yang harus segera dicermati oleh IDF, agar dapat kembali pada subtansi 'tari' yang sesunguhnya. Karena, tanpa diembel-embeli wacana lintas disiplin dan keterlibatan pihak di 'luar' ranah tari pun, IDF akan tetap memberikan ruang gerak yang jelas akan keberlangsungan tari kontemporer Indonesia. Tari tidak hanya dipadang dari hasil produknya saja tetapi juga dari proses kinestetik dan ketubuhan para penari dan pencipta tari itu sendiri. Dengan kata lain, orang atau pihak di luar tari (apalagi di Indonesia) seharusnya memahami kompleksitas ketubuhan ini terlebih dahulu, sebelum melanjutkannya dengan mengaitkan persoalan tubuh dengan wacana dan sudut pandang disiplin seni yang lain.

Tentu tidak ada yang salah dengan perlintasan antar disiplin seni, terutama penting sekali dengan perkembangan seni kontemporer saat ini menunjukkan kelekatannya dengan kemajuan teknologi. Hanya saja, terutama untuk kasus Indonesia, perlu disadari betul bahwa ketuntasan proses ketubuhan penari dan koreografer tidak dapat semata-mata diloncati sebelum kemudian mampu bersentuhan dengan unsur seni lain; karena bagaimanapun, tubuh adalah modal dan media utama dari sebuah karya tari. Alih-alih memberikan kemajuan, tubuh yang belum tuntas hanya akan berpijak pada akar yang goyah ketika harus menanggung berbagai lintasan seni yang ditampung dalam karyanya. Sebuah malapetaka, jika karya seni tari berpijak hanya pada idealisasi konsep dan teori, tanpa mengandalkan tubuh sebagai sumber utama penciptaannya.

\section{Sasikirana Dance Camp dan Harapan Tubuh Tari Indonesia}

Program Dance Camp dan KoreoLab ini muncul sebagai alternatif kegiatan yang memberikan kesempatan bagi seniman tari muda di seluruh pelosok Indonesia, utamanya untuk mempertegas posisi, cara kerja hingga sudut pandang pemahaman studi tubuh pada tari Indonesia. Sasikirana Dance Camp (SDC) adalah sebuah wadah untuk berkumpulnya penari dari berbagai daerah di Indonesia untuk, memulai dialog tubuh, berproses bersama serta melakukan kontrol organik ketubuhan untuk memahami elemen dasar tari, yaitu tubuh. Para perserta kegiatan ini melakukan penjelajahan menelusuri netralitas tubuh yang tidak lagi mengacu pada vokabuler tari tradisi tertentu. Penari menyelami diri lebih dalam untuk menemukan identitas pribadi dan keunikan dari masing-masing individu, dan kemudian merajutkan pendekatan fisikal dan kinestetik untuk mencapai sebuah gagasan dalam menciptakan karya tari (koreografi) kontemporer.

In our bodies lives our stories (di dalam tubuh kita terkandung cerita kita) -sebuah pernyataan dari Annanya Chattarjee, penari, koreografer dan professor tari di Univerity of Minnesota, Amerika Serikat (wawancara Annanya Chattarjee, 20014). Layak untuk dijabarkan, dengan adanya 17.000 kepulauan yang ada di Indonesia dari Sabang sampai Merauke, setiap individu memiliki potensi tubuh tradisi yang berkaitan dengan memori dan kolektifitas ragam gerak. Potensi keragaman tubuh inilah yang dipercaya SDC sebagai kekuatan dari masing-masing etnis di Indonesia, pelaksanaan SDC pertama pada tahun 2015 dilanjutkan dengan SDC kedua pada tahun 2016.

Pada ilmu ketubuhan (embodiement), dikenal kata agen atau agensi (agency), dalam menggambarkan perilaku manusia dalam kebertubuhannya, yaitu yang mengaitkan proses tubuh dengan pengalaman. Penelitian lebih lanjut mengenai hal ini menciptakan teori agen dan agensi, seperti yang tertuang dalam buku Agency and Embodiment karya Carrie Noland (2009: 187), yang 
mendefinisikan agen sebagai berikut, "The power to alter those acquired behaviors and beliefs for purposes that may be reactive (resistant) or collaborative (innovative) in kind." (Sebuah kekuatan untuk mengubah perilaku yang diperoleh oleh seseorang dan keyakinan untuk tujuan yang dapat bersifat reaktif (tahan) atau kolaboratif (inovatif) dalam berbagai bentuk).

Dalam ranah sosiologi, agensi dapat diartikan sebagai individu yang terlibat dan terikat dalam sebuah kultur sosial. Individu memiliki kapasitas dalam bertindak, dan membuat pilihan serta menentukan keputusan. Hal tersebut menempatkan manusia yang bertindak sebagai agen atau agensi, yang bertanggung jawab atas kelangsungan sebuah kebudayaan. Pernyataan ini berkaitan dengan teori strukturalis Pierre Bourdieu (1977: 79) dalam konsep habitus yang disampaikannya sebagai,

The habitus, the durably installed generative principle of regulated improvisations, produces practices which tend to reproduce the regularities immanent in the objective conditions of the production of their generative principle.

(Habitus, merupakan prinsip generatif yang menubuh melekat dengan improvisasi yang diatur, menghasilkan praktik yang cenderung mereproduksi keteraturan imanen dalam kondisi objektif dari sebuah prinsip generatif produksi).

Pernyataan Bourdieu secara tersirat menyatakan bahwa habitus memengaruhi seorang individu dan masyarakat dalam melakukan sebuah tindakan. Begitupun dalam seni tari kontemporer, tubuh yang bergerak dan membawa pesan moral akan menanggung konsekuensi dari apa yang disampaikan. Hal ini berkaitan dengan latar belakang kultural yang membangun sebuah terbentuknya sebuah gerak tari.

Konsep yang sama disampaikan juga oleg McLuhan (1994) dalam Supartono (2016) yang berpendapat bahwa tubuh tidak lagi dilihat oleh publik sebagai alat atau media tapi tubuh itu sendiri oleh publik dilihat sebagai gagasan atau ide. Tubuh langsung menjadi pesan itu sendiri. Dalam proses penciptaan teater tubuh, publik atau penonton diberi kesadaran kembali pada tubuh yang selama ini dilupakan keberadaannya, seperti dalam mal atau tempat perbelanjaan yang mewah. Dengan kata lain, tindakan, persepsi dan interpretasi yang dimaterialisasi oleh seniman tari dalam bentuk gerak merupakan sebuah hasil yang jujur terhadap habitus yang selama ini membentuk dirinya secara organik. Tubuh tidak dapat melepaskan diri dari sejarah dan memori kultural yang telah tertanam di dalam dirinya, namun setiap tubuh sedianya memiliki kontrol terhadap ekspresi dirinya, yang dalam hal ini dimunculkan dalam bentuk tari.

Pilot project Sasikirana Dance Camp pada tahun 2015 dilaksanakan dengan memperkokoh metoda pelatihan tari yang dilakukan secara intensif dengan melibatkan penari dari berbagai latar belakang kultur, sejarah dan cerita pada tubuhnya. Hal ini dilakukan dengan dasar kepercayaan bahwa setiap penari memiliki tubuh dan memori tradisi dari masing-masing kultur yang menjadi alat utama, untuk kemudian melakukan dekonstruksi terhadapnya hingga ditemukan bentuk ekstraksi dan definisi netral dari masing-masing pribadi penari. Camp atau workshop intensif yang dilakukan selama tujuh sampai sepuluh hari ini meramu sebuah dedikasi terhadap kebesaran kompleksitas tubuh dari para penari dan koreografer.

SDC secara khusus melaksanakan kegiatannya menggunakan konsep specific site performance yang bertempat di NuArt Scupture Park di Bandung. Workshop ini menekankan kepenarian dan ketubuhan lengkap dengan segala pendekatan fisikalnya, serta dipresentasikan dalam karya pertunjukan yang merespon langsung kondisi lingkungan di sekitarnya. Lingkungan yang dimaksud adalah perpaduan antara 
ruang lokal natural alam dan ruang artefak yang menempatkan karya-karya patung Nyoman Nuarta sang pemilik ruang seni tersebut, di mana perpaduan ini menjadi bagian yang penting untuk disepakati dalam merespon dan mengkolaborasikannya sebagai ruang pertunjukan. Sebagai hasilnya, ruang seni tari, teater dan rupa dikemas dalam sebuah karya pertunjukan yang terikat menjadi satu keseimbangan dalam presentasi hasil workshop intensif SDC 2015 bertema Double Dare Dance.

Peserta yang dipanggil secara terbuka (open call) dipilih melalui seleksi berasal dari berbagai institusi seni/komunitas/sanggar/ individu yang telah memiliki latar belakang seni pertunjukan. Para pendaftar merupakan penari yang tidak hanya berasal dari kawasan Indonesia, namun juga dari kawasan regional Asia Tenggara. Dua puluh lima peserta terpilih kemudian dibagi ke dalam tiga kelompok rotasi untuk mendapatkan materi melalui bimbingan para mentor yang terdiri dari Jecko Siompo (penari dan koreografer), Melati Suryodarmo (seniman seni rupa pertunjukan), Wawan Sofwan (aktor dan sutradara teater) dan Eko Supriyanto (penari dan koreografer). Akhir dari pelaksanaan SDC 2015 dilanjutkan dengan sebuah presentasi berjudul Menjaring Bulan yang penampilannya berinteraksi dengan karya instalasi bambu dari perupa Joko Avianto, diselenggarakan pada tanggal 28

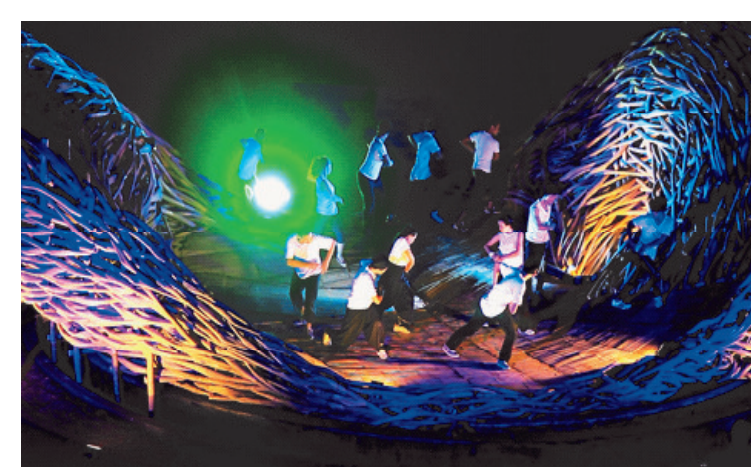

Gambar 2. Presentasi hasil workshop Sasikirana Dance Camp 2015, penari merespon instalasi bambu karya Joko Avianto. Foto: Tim Dokumentasi SDC 2015.

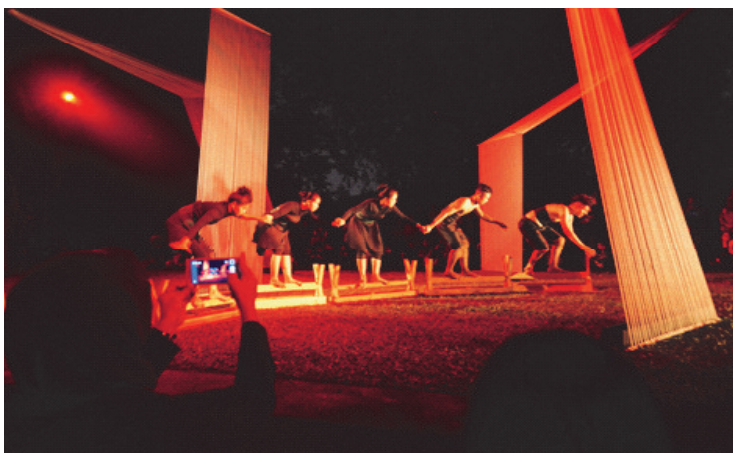

Gambar 3. Presentasi hasil workshop Sasikirana KoreoLAB \& Dance Camp 2016. Work-inprogress karya Yudi Tancker (Pekanbaru) yang dieksplorasi selama KoreoLAB berlangsung, berinteraksi dengan karya instalasi Rubiadhi Roesli. Foto: Tim Dokumentasi SKDC 2016.

Juli 2015. Dengan dukungan dari Yayasan Kelola dalam Hibah Karya Inovatif, hasil workshop intensif ini dipentaskan dalam sebuah perpaduan karya seni tari, teater, dan rupa berdurasi 60 menit.

Melanjutkan kegiatan pertamanya, Sasikirana Dance Camp 2016 yang bertema Dance, City, Density diselenggarakan pada tanggal 1-9 Agustus 2016 berlokasi di tempat yang sama, yaitu NuArt Sculpture Park, Bandung. Pada tahun 2016, SDC memberikan tambahan kegiatan dengan menggunakan pendekatan koreografis untuk penata tari kontemporer, sehingga SDC 2016 sedikit berkembang dan berubah nama menjadi Sasikirana KoreoLAB dan Dance Camp (SKDC). Selama sembilan hari berturut-turut, sebanyak enam koreografer dan duapuluh lima penari yang sebelumnya telah melalui sebuah proses seleksi serupa dengan pelaksanaan SDC 2015, menjalani karantina, tinggal bersama, mengolah tubuh dengan kegiatan latihan fisikal, mengolah dan mempertajam daya tahan tubuhnya.

Para peserta Dance Camp dan KoreoLab ini difokuskan untuk membentuk kesadaran fisikal dengan mengelaborasi materi-materi workshop dari para mentor. Lebih lanjut lagi, proses kesadaran fisikal sebagai penari dan koreografer ini tidak hanya dipahami dalam konteks kinestetik belaka, namun pemahaman terpenting ter- 
letak pada bagaimana penari dan koreografer memahami kompleksitas otot dan keringat serta daya tahan fisikalnya ketika sudah dapat menggembalikan dirinya melalui studi tubuh yang nyata. Selanjutnya, peserta diajak untuk mengalami benar bagaimana sebuah pemahaman terhadap konsep kinestetik dapat dijadikan titik tolah wacana dan studi pada proses kekaryaannya. Mereka diberi kesempatan untuk merasakan dan mendiskusikan pengalaman ini sehingga akhirnya mampu memberikan konstribusi pada proses kepenarian dan kekaryaannya sendiri.

Konsep empati kinestetik diperiksa dari perspektif neurofisiologi kinesthesia atau kesadaran tubuh dalam menciptakan sensasi melalui gerak, diciptakan oleh ranah pikiran dan dihantarkan ke ranah otot dan sendi, serta sistem artikular (Fostese, 2011: 13). Kinesthesia didesain untuk memproduksi stimulasi terhadap sensor tubuh (Foster, 2011). Hal ini membuka sebuah bidang bagi untuk mempertanyakan reflektivitas dari tubuh dan menjadikannya sebagai objek. Penari, dalam hal ini tentu saja bergerak dengan kesadaran tubuh untuk menyampaikan apa yang mereka rasakan. Pemikiran kemudian diterjemahkan oleh pergerakan sendi dan otot, dan barulah pendefinisian dan proses kinesthesia itu bekerja. Menurut Susan Leigh Foster dalam bukunya Choreographing Empathy: Kinesthesia in Performance (Fostese, 2011: 67.) Kinesthesia adalah tanggapan terhadap sebuah penelitian yang menyatakan bahwa keberadaan sensor saraf pada otot dan sendi memberikan dampak terhadap estetika tari. Ketika terjadi pembahasan tentang peran penari dalam koreografi dan penyajiannya, maka berbagai sudut pandang mulai bermunculan.

Pelaksanaan SKDC 2016 berhasil menjaring duapuluh lima peserta yang terdiri dari seniman tari, penari maupun koreografer muda yang aktif berkarya tari, yang mewakili delapan belas kota/kabupaten di Indonesia, empat negara di Asia Tenggara, dan satu peserta dari Amerika Serikat. Enam orang peserta KoreoLab dipilih secara penunjukan langsung dengan mempertimbangkan keaktifan peserta dalam mencipta tari, upaya peningkatan skill dan materi penciptaan karya tari kontemporer berbasis pemahaman kompleksitas ketubuhan dan pendekatan fisikal. Perserta terpilih berasal dari Singapura, Padang Panjang, Tanjung Pinang, Bandung, Bali, dan Makassar.

Selain itu, mentor yang dilibatkan antara lain adalah Fathurrahman bin Said, seniman tari Singapura berbasis tari Melayu. Pengalamannya menata tari dengan idiom budaya Melayu dikembangkan dengan proses mendekonstruksi berbagai repertoar, menyinggung bahwa kekuatan tradisi justru semakin gemilang jika kita dapat mengikutsertakannya dalam kancah gagasan kekinian. Ia berpendapat bahwa dalam berkesenian, kita hanya memerlukan tiga hal, yaitu berkarya dengan keikhlasan, bergerak dengan kejujuran, dan bertanggung jawab terhadap karya yang dihasilkan.

Arco Renz dari Jerman/Belgia, murid angkatan pertama dari salah satu sekolah tari paling penting di Eropa, yaitu PARTS, telah banyak menjelajahi tradisi Asia Pasifik, di antaranya Indonesia. Renz menyatakan bahwa yang dia pelajari di Indonesia adalah pembelajaran tari yang sangat bermakna untuk menjalin mata rantai mozaik kebudayaan Indonesia.

Seni tari di Indonesia terbentuk dalam lintasan kebudayaan yang plural dan saling berkaitan satu sama lain. Hal yang menjadi tantangan besar bagi para seniman tari Indonesia adalah bagaimana menciptakan karya dalam kondisi 'multi-polar' ini, dan bagaimana pada saat yang sama mesti mampu bersimpangan dalam dimensi ruang dan waktu yang dinamis, mensinergikan gaya tradisional dengan gaya pergerakan terkini, masa lampau dengan sekarang, lokal dengan global (Gebrindius, 2016: 14 ). 
Keni K. Soeriaatmadja, penari dan anggota kelompok Bengkel Tari Ayu Bulan di Bandung yang juga memiliki posisi sebagai program director di NuArt Scupture Park, merupakan pendiri dan pimpinan produksi SDC dan SKDC. Soeriaatmadja berpendapat bahwa dipilihnya NuArt Sculpture Park menjadi tuan rumah kegiatan ini adalah karena melihat lingkungan tempatnya yang menantang para seniman tari untuk kembali mendekat dengan alam. Selama ini, aspek tontonan telah menjebak para penari dalam ruang non-alam yang meski memberikan banyak kemudahan bagi penari dan karya cipta tari kontemporer, namun membuat para pelaku menjadi terlena dan menjauh dari akar asal tubuhnya (press release SKCD, 26 Juli 2016). SKDC merangkum seni tari, musik, visual, dan arsitektur berjalinan secara komplementer dalam kerangka presentasi specific site (press release SKCD, 26 Juli 201).

Melihat dan belajar dari keberhasilan tahun pertama dan kedua, sesuai komitmen untuk melaksanakan program tersebut pada setiap tahun, penyelenggara kembali menerima tigapuluhan penari dan koreografer muda pada tahun 2017, dengan tema Afer Dance. "Tubuh dirayakan sebagai tuan rumah untuk ekspresivitas kreatif dalam sebuah karya. Bagaimana tubuh tari Indonesia tidak lagi mengandalkan keindahan eksotik dan domestik, " demikian kutipan isi pengantar pada buku program kegiatan Sasikirana KoreoLAB \& Dance Camp 2017 yang dipaparkan oleh Renee Sariwulan, seorang pengamat seni pertunjukan Indonesia yang berdomisili Yogyakarta. Selain melibatkan Renee sebagai penulis, SKDC 2017 juga menghadirkan beberapa ahli dalam seni pertunjukan lain, yaitu Lim How Ngean (dramaturg asal Malaysia yang berdomisili di Melbourne, Australia), Melanie Lane (koreografer dan penari asal Melbourne, Australia), Eko Supriyanto (koreografer dan penari asal Surakarta), Har- tati (koreografer dan penari dari Jakarta), Iwan Irawan (koreografer dan penggagas PASTAKOM dari Pekanbaru), dan Ali Sukri (koreografer dan penari dari Padang Panjang). Program ini akan berlangsung pada tanggal 3-9 September 2017 yang juga diadakan di kawasan kompeks NuArt Sculpture Park, Bandung.

\section{SKDC dan Kembalinya Studi Tubuh}

Dalam SCDC 2016, peserta dituntut untuk meningkatkan pengetahuan dan pengalamannya dengan cara memaparkan gagasan karya tari yang pernah dilakukannya, berdiskusi dan mempresentasikan secara fisikal karya yang dikerjakan dalam program tersebut. Kegiatan ini berlangsung intensif dengan proses mentoring yang berlangsung secara rotasi, di mana setiap peserta memiliki kesempatan yang sama untuk berinteraksi dengan mentor. Intensitas ini menciptakan relasi timbal balik antara para peserta dengan para mentornya yang merupakan koreografer dan penari profesional ini, di mana masukan pandangan dan referensi yang diberikan selalu mengembalikan semua idea kepada studi tubuh sebagai sasaran utama untuk meningkatkan kepekaan agensi ketubuhan, dengan tujuan agar semua mencapai pemahaman proses kinestetik dalam penciptaan karya tarinya.

\section{Tubuh Tari Indonesia Mendatang}

Perkembangan dan perubahan yang terjadi di tiap zaman seharusnya membuat penari semakin memahami persoalan tentang tari sebagai upaya ekspresi diri yang disampaikan melalui capaian-capaian tertentu. Pada era 1950-an sampai 1970 -an, tari sudah mengalami modernitas, sehingga membuat pemahaman masyarakat menjadi lebih mengutamakan nilai-nilai (values), kualitas, dan dimensi-dimensi gerakan.

Salah satu hal yang penting dari peran Sardono dalam memelihara kesenian 
adalah saat ia mulai melukis, karena dengan itu ia menyatakan bahwa kompleksitas ketubuhan penari dapat ditantang ke dalam zona-zona lain yang lebih nonkonvensional. Penari juga wajib masuk ke dalam galeri dan ruang-ruang yang bersifat statis (wawancara Kusumo, 2011). Proses pengalaman dan pembangkitan memori tubuh dilakukan dengan merambah zonazona baru dalam seni pertunjukan kontemporer. Sardono, yang proses kreatif dan pengalamannya membuat pola-pola yang tidak biasa mengatakan kepada penari untuk, "jangan bicara estetika dulu, tetapi training dulu, visi dulu, karena dibalik itu ada pesan yang tersembunyi" (wawancara Kusumo, 2011). Sardono mengutamakan proses dan latihan dalam tari sebagai sebuah pengalaman tubuh untuk karya. Tari telah memiliki batasan-batasan teknik, estetik, dan visual, di mana pada era globalisasi terdapat tuntutan dari masyarakat: penikmat, pemilik, pemerhati, dan pelakunya.

Para pelaku tari pada akhirnya juga telah banyak disadarkan, bahwa tari dapat lebih leluasa memasuki, menembus, dan melampaui batas-batas yang selama ini tidak pernah terusik keberadaannya. Tari dapat menelusuri kehidupan dan intisarinya setelah proses ketubuhannya dituntaskan. Tari adalah tubuh dan ketika tubuh dapat tertuntaskan training dan proses pembentukan tubuh dengan materi-materi dan repertoar gerak tari tradisi misalnya; tubuh itu kemudian mengawalinya dengan sebuah proses penciptaan dan proses penciptaan ini harus melewati tahap untuk 'menjajal' tubuh dan referensi kompleksitasnya dalam zona-zona yang tidak lagi nyaman. Latihan yang terus-menerus dan menjelajahi zona-zona baru, memberikan sebuah pengalaman tubuh yang tidak terbatas. Hal ini akan mendorong terjadinya pembentukan ataupun penciptaan gagasan, potensi atau kapasitas serta keterampilan, teknik dan kepekaan interdisiplin bidang apapun, maupun gagasan besar dalam cakupan persilangan budaya. Gagasan ini membuat tubuh menjadi transparan karena saling menyerap bentuk, nilai, visual, auditif, tactile, pencerapan dan penciuman. Struktur dari subjek lingkungan tidak dibekukan di dalam kerangka koreografi, namun luluh dalam interelasi ko-eksistensial dengan subjek-subjek di sekitarnya.

\section{SIMPULAN}

Gagasan Sardono dalam pencarian idiom dan inspirasi dalam sebuah proses tari sangat perlu dipahami karena tari tidak hanya sebatas gerak yang disusun, tetapi merupakan sebuah peristiwa budaya. Gagasan ini membalut karya-karya tari yang merupakan respons penghayatan dari seniman terhadap kehidupan yang dilatar belakangi kehidupan keluarga, norma-norma, sosial budaya, dan pendidikannya.

Terkait dengan apa yang dikatakan Bourdieu (1977: 79) pada proses penciptaan sebuah gagasan, Sal Murgiyanto (2012: 118) berpendapat bahwa manusia hanya dapat memberikan bentuk berdasarkan apa yang diketahui dan dialaminya. Pengetahuan dan pengalaman inilah yang kemudian diolah secara terus-menerus, dipertanyakan, dielaborasi ke dalam konsep, dimaterialisasi ke dalam bentuk gerak, diintervensi, ditantang signifikansinya melalui serangkaian reinterpretasi, dilatihkan dan akhirnya ditampilkan dalam sebuah eksekusi koreografi yang matang. Dengan demikian keberhasilan seorang penata tari dalam menggarap sebuah karya tari membutuhkan keterampilan, luasnya pandangan, dan kekayaan alam jiwanya. Dalam hal ini, setidaknya terdapat tiga hal yang wajib menjadi bekal dari seorang penata tari, yakni, spontanitas dan daya intuisi, keterampilan menata bentuk, pemahaman akan prinsip dan kemampuan untuk merumuskan makna.

Penjabaran Bourdieu (1977: 79) tentang habitus mempertegas kapasitas aktif seni- 
man untuk berpartisipasi dalam pembangunan makna budaya. Tubuh berperan sebagai repositori dari bentuk memori budaya yang belum pernah didokumentasikan dalam sejarah. Melihat perkembangannya, penulis merasa bahwa SKDC sepertinya mampu memberikan alternatif untuk sebuah proses yang menyoroti dan merayakan habitus tubuh tari penari Indonesia. Bourdieu menegaskan pentingnya melakukan kegiatan lebih dari menghafal dan memperingati dasarnya konservatif gerak tubuh dalam sebuah repertoar tari tradisi; gerak tubuh dengan repertoar mempertahankan dan selalu berlekatan dengan sejarah yang setelahnya harus mampu berimprovisasi dan melakukan pertanyaan-pertanyaan kreatif atas tindakan (gerak) yang berfungsi untuk menemukan kembali dan memperbaharui sikap tradisi pemikiran dan tindakannya. Tampaknya, konsep SKDC berkesesuain dengan Bourdieu sehingga SKDC berpotensi mampu menempatkan tubuh dalam peran kendaraan untuk tubuh yang lain atau tubuh pasca-tradisi. Dengan demikian, tubuh dapat mengidentifikasi dirinya sebagai kendaraan untuk menyalurkan budaya, menciptakan budaya baru, dan sebagai ungkapan budaya kekinian.

SKDC menawarkan sebuah intensi mendasar untuk mengolah gagasan dan ide melalui impuls fisikal terlebih dahulu, baru kemudian dengan melakoni banyak latihan, diskusi dan dialog bersama rekan koreografer, penari dan mentor, sebuah karya tari dapat tercipta dengan memberikan ruang tafsir ekspresi gerak tubuh yang lengkap dengan agensi kinestetiknya. Tubuh dirayakan menjadi tuan rumah untuk ekspresivitas kreatif dalam sebuah karya. Gagasan naratif yang mengandung pesan kultural maupun domestik, digantikan dengan kompleksitas ketubuhan yang han- dal, bersinergi pada ruang spesifik, dan kemudian melontarkan abstraksi gagasan dalam ruang tafsir yang lebih netral, yang tidak lagi mengetengahkan eksotisme narasi atau teks kultural domestik.

\section{Daftar Pustaka}

Bourdieu, P. (1977). Outline of a Theory of Practice. Cambridge: Cambridge University Press.

Chattarjee, A. (2004). Butting Out, Reading Resistive Choreographies Through Works by Jawole Willa Jo Zollar and Chandralekha. Middletown, Connecticut: Wesleyan University Press.

Forsythe, W. (2011). And the Practice of Choreography. London: Routledge.

Foster, S. L. (2011). Choreographing Empathy: Kinesthesia in Performance. London: Routledge.

Noland, C. (2009). Agency and Embodiment: Performing Gestures/Producing Culture. London: Harvard University Press.

Murgiyanto, S. (2008). Menulis Kritik Seni dalam Krisis Kritik, Seperempat Abad Pasca Gendhon Humardani. Surakarta: ISI Press Surakarta.

--------. (2005). Membaca Sardono: PenariPenata Tari, Pejalan dan Pemikir Budaya. Tiga Jejak Seni Pertunjukan Indonesia. Editor: Tommy F. Awuy. Jakarta: Masyarakat Seni Pertunjukan Indonesia.

(2004). Tradisi dan Inovasi, Beberapa Masalah Tari di Indonesia. Jakarta: Wedatama Widya Sastra.

Supriyanto, E., Haryono, T., Soedarsono, Moergiyanto, S. (2014). “Empat Koreografer Tari Kontemporer Indonesia Periode 1990-2008". Panggung, 24, (4), 335-350.

Supartono, T. (2016). “Penciptaan Teater Tubuh". Panggung, 26 (2), 208-221. 